\title{
Time partitioning among jaguar Panthera onca, puma Puma concolor and ocelot Leopardus pardalis (Carnivora: Felidae) in Costa Rica's dry and rainforests
}

\author{
Hansel Herrera ${ }^{1}$, Elpis J. Chávez ${ }^{2}$, Luis D. Alfaro ${ }^{3}$, Todd K. Fuller ${ }^{4}$, Victor Montalvo ${ }^{3,4}$, \\ Flávio Rodrigues ${ }^{5} \&$ Eduardo Carrillo ${ }^{3,4}$ \\ 1. Iniciativa Osa-Golfito, Stanford University, California, USA; bluecloudcr@gmail.com \\ 2. Centro de Rescate de Especies Marinas Amenazadas, Heredia, Costa Rica; echavk@gmail.com \\ 3. Instituto Internacional en Conservación y Manejo de Vida Silvestre, Universidad Nacional, Heredia, Costa Rica; \\ alfaroalvarado@gmail.com,vmontalvog@gmail.com, eduardo.carrillo.jimenez@una.cr \\ 4. Department of Natural Resources Conservation, University of Massachusetts, Amherst, USA; \\ tkfuller@eco.umass.edu \\ 5. Universidade Federal de Minas Gerais, Dept. Biologia Geral. Minas Gerais, Brasil; rodriguesfhg@gmail.com
}

\author{
Received 05-IV-2018. Corrected 18-VII-2018. Accepted 06-IX-2018.
}

\begin{abstract}
Segregation of daily activity patterns is considered an important mechanism facilitating the coexistance of competing species. Here, we evaluated if temporal separation existed among jaguar (Panthera onca), puma (Puma concolor) and ocelot (Leopardus pardalis) and if their activity patterns were related to that of a particular prey. We used camera trap records to estimate the activity schedules of these predators and their prey. We used the coefficient of overlapping ( $\Delta$; ranging from 0 to 1 ) to quantify the temporal interactions between predators and prey, and calculated confidence intervals from bootstrap samples. Strong temporal overlap occurred among the three felids $(\Delta=0.63-0.82)$ in both dry and rainforests. However, a greater temporal separation was observed between the closest competitors (jaguar and puma, puma and ocelot). Jaguar and puma had a strong temporal overlap with medium and large-sized prey, while ocelots' activity matched that of smallsized prey. High overlapping coefficients among the felids suggest that temporal segregation is not the main mechanism facilitating their coexistence in these areas. However, fine-scale or spatiotemporal differences in their activity patterns might contribute to their coexistence in tropical environments.
\end{abstract}

Key words: activity patterns; coexistence; Corcovado National Park; Guanacaste Conservation Area; interference competition; time partitioning; wild felid.

Herrera, H., Chávez, E. J., Alfaro, L. D., Fuller, T. K., Montalvo, V., Rodrigues, F., \& Carrillo, E. (2018). Time partitioning among jaguar Panthera onca, puma Puma concolor and ocelot Leopardus pardalis (Carnivora: Felidae) in Costa Rica's dry and rainforests. Revista de Biología Tropical, 66(4), 1559-1568.

Niche segregation is frequently proposed as a mechanism by which multiple species may coexist (MacArthur \& Levins, 1967; Schoener, 1974; Karanth \& Sunquist, 2000; Davies, Meiri, Barraclough, \& Gittleman, 2007). Partitioning of resources in ecological communities may occur along the space, time, and/or food axes (Schoener, 1974). Traditionally, most studies have focused on the spatial and trophic dimensions to assess the mechanisms underlying the coexistence of species (Schoener, 1974). Although time has being considered an important organizing factor in structuring ecological communities (Dayan \& Simberloff, 2005; Davies et al., 2007), its role as a mediator of ecological interactions is poorly understood 
(Kronfeld-Schor \& Dayan, 2003). This is especially true for tropical forest communities, particularly the large and medium-sized animals which tend to be shy, elusive and may occur at naturally low population densities (Linkie \& Ridout, 2011).

Jaguars (Panthera onca), pumas (Puma concolor) and ocelots (Leopardus pardalis) are sympatric over much of their range (GonzalezBorrajo, Lopez-Bao, \& Palomares, 2016). The three felids have been described as opportunistic hunters (Emmons, 1987; Taber, Novaro, Neris, \& Colman, 1997; Sunquist \& Sunquist, 2002) whose diets frequently overlap, making them potential competitors. Agonistic interactions among them are reported in the literature (Mondolfi \& Hoogesteijn, 1986; Crawshaw, 1995; Nuñez, Miller, \& Lindzey, 2000; Harmsen, Foster, Silver, Ostro, \& Doncaster, 2009), with the puma most likely being dominant over the ocelot and the jaguar over both of these, based on body size differences (Schaller \& Crawshaw, 1980; Di Bitetti, Angelo, Di Blanco, \& Paviolo, 2010). Given the high dietary overlap observed between jaguars and pumas (Emmons, 1987; Taber et al., 1997; Nuñez et al., 2000; Crawshaw \& Quigley, 2002; Leite \& Galvaõ, 2002; Scognamillo, Maxit, Sunquist, \& Polisar, 2003; Novack, Main, Sunquist, \& Labisky, 2005) and between pumas and ocelots (Emmons, 1987; Rabinowitz \& Nottingham, 1986; Sunquist \& Sunquist, 2002), coexistence among these felids suggests they have evolved behavioral traits that ecologically separate them or that resources are abundant enough that sharing does not negatively affect either species (Emmons, 1987; Nuñez et al., 2000).

Interference competition has been proposed as a key factor promoting temporal separation between jaguars and pumas (Emmons, 1987; Harmsen et al., 2009; Romero-Muñoz, Maffei, Cuéllar, \& Noss, 2010). Avoidance of temporal overlapping eliminates the negative effects of interference interactions (i.e., harassment, robbing, killing, etc.) and has been observed in competing species of desert rodents (Kenagy, 1973; O’Farrell, 1974), foxes (Di Bitetti, Di Blanco, Pereira, Paviolo, \& Pérez, 2009), felids
(Azlan \& Sharma, 2006; Di Bitetti et al., 2010) and canids (Arjo \& Pletscher, 1999), among other taxa (Kronfeld-Schor \& Dayan, 2003; Barrull et al., 2014). In this paper, we evaluated if temporal separation existed among three species of neotropical felids and if their activity patterns were related to that of a particular prey. Carnivores with similar body sizes tend to eat similarly sized prey (Rosenzweig, 1966), thus increasing the probability of interspecific competition and intraguild aggression (Donadio \& Buskirk, 2006). We hypothesized that, as a result of interference competition, the pairs of cats with the highest morphological similarity (puma-jaguar and puma-ocelot) would exhibit a stronger temporal segregation than the leastsimilar (jaguar and ocelot).

\section{MATERIALS AND METHODS}

Study site: Corcovado National Park (CNP) is a $500 \mathrm{~km}^{2}$ expanse of tropical rainforest located in Southwestern Costa Rica. It comprises a mosaic of primary and secondary forests from 0-700 masl. The climate is hot and humid, with mean annual temperature of $25^{\circ} \mathrm{C}$ and mean annual precipitation of $4000 \mathrm{~mm}$, with pronounced wet (May-November) and dry (December-April) periods (Carrillo, 2000).

Santa Rosa National Park (SRNP) is a 387 $\mathrm{km}^{2}$ expanse of tropical dry forest located in Northwestern Costa Rica. It comprises a mosaic of second-growth forests from 0-500 masl. Annual temperature ranges from $16-38{ }^{\circ} \mathrm{C}$ (mean $28{ }^{\circ} \mathrm{C}$ ) and precipitation ranges from 900-2 500 mm (mean 1600 mm) (Janzen, 1988; Pacheco, 1994).

Camera-trap data collection: Cameratrap data were collected from 87 locations inside the CNP between 2003-2015, and from 61 locations inside the SRNP between 20052015. Cameras were located along forest trails, unused dirt roads and near water sources (in SRNP only) with a minimum distance of $2.5 \mathrm{~km}$ from one another (Silver et al., 2004). They were programmed to operate 24 $\mathrm{h} \mathrm{d}^{-1}$ and to record the date and time of each 
photograph with a minimum delay of $10 \mathrm{~min}$. We used Bushnell Trophy Cams for most of our study, although Cam Trakker and Stealth cameras were also employed during the first years of research.

Statistical analysis: To quantify the overlap between the activity periods of the felids and their prey, we used the two-step approach developed by Ridout \& Linkie (2009). First, we determined the daily activity patterns of each predator and prey species using kernel density estimates. This method presupposes that the animals are equally likely to be photographed at all times when they are active (Ridout \& Linkie, 2009), and treats pictures as random samples from an underlying continuous distribution instead of grouping them into discrete time categories (Foster et al., 2013). The second step consisted on estimating the degree of overlapping between two probability functions. We used the coefficient of overlap $(\Delta)$, defined as the area under the curve that is formed by taking the minimum of the two density functions at each time point (Linkie \& Ridout, 2011). The coefficient of overlap ranges from 0 (no overlap) to 1 (complete overlap) (Ridout \& Linkie, 2009; Linkie \& Ridout, 2011). We used the $\Delta_{1}$ and $\Delta_{4}$ estimators recommended for small and large samples, respectively, and calculated confidence intervals as percentile intervals from 1000 bootstrap samples (Ridout \& Linkie, 2009). Analyses were performed in the software $\mathrm{R}$ and the package Overlap ( $\mathrm{R}$ Development Core Team, 2017).

\section{RESULTS}

A total of 5506 photographic records (including animals and people) were collected

TABLE 1

Estimates of activity pattern overlap between the jaguar, puma and ocelot and their presumed prey species in the Santa Rosa National Park (SRNP), Costa Rica

\begin{tabular}{|c|c|c|c|c|}
\hline \multirow{2}{*}{ Species } & \multirow{2}{*}{$\mathrm{n}^{*}$} & \multicolumn{3}{|c|}{ Coefficient of overlap ( $95 \%$ Confidence interval) } \\
\hline & & Panthera onca & Puma concolor & Leopardus pardalis \\
\hline Procyon lotor & 58 & $0.821(0.735-0.938)$ & $0.703(0.572-0.818)$ & $0.792(0.703-0.916)$ \\
\hline Tapirus bairdii & 220 & $0.818(0.765-0.878)$ & $0.609(0.501-0.706)$ & $0.846(0.789-0.923)$ \\
\hline Conepatus semistriatus & 107 & $0.745(0.653-0.833)$ & $0.665(0.562-0.770)$ & $0.739(0.633-0.830)$ \\
\hline Didelphis marsupialis & 58 & $0.736(0.595-0.811)$ & $0.582(0.456-0.688)$ & $0.802(0.708-0.905)$ \\
\hline Canis latrans & 23 & $0.687(0.531-0.833)$ & $0.716(0.556-0.851)$ & $0.582(0.399-0.708)$ \\
\hline Odocoileus virginianus & 931 & $0.629(0.551-0.671)$ & $0.799(0.724-0.871)$ & $0.513(0.421-0.561)$ \\
\hline Dasypus novemcinctus & 19 & $0.606(0.413-0.739)$ & $0.498(0.320-0.632)$ & $0.648(0.474-0.791)$ \\
\hline Panthera onca & 259 & - & $0.737(0.648-0.817)$ & $0.823(0.770-0.904)$ \\
\hline Leopardus pardalis & 127 & $0.825(0.767-0.906)$ & $0.641(0.531-0.744)$ & - \\
\hline Nasua narica & 85 & $0.454(0.332-0.504)$ & $0.656(0.511-0.738)$ & $0.354(0.220-0.403)$ \\
\hline Aramides cajanea & 59 & $0.452(0.324-0.516)$ & $0.655(0.506-0.730)$ & $0.348(0.214-0.405)$ \\
\hline Dasyprocta punctata & 482 & $0.461(0.381-0.496)$ & $0.631(0.532-0.696)$ & $0.343(0.241-0.382)$ \\
\hline Penelope purpurascens & 83 & $0.446(0.337-0.497)$ & $0.634(0.499-0.718)$ & $0.339(0.219-0.392)$ \\
\hline Puma concolor & 97 & $0.747(0.640-0.820)$ & - & $0.639(0.531-0.747)$ \\
\hline Tigrisoma mexicanum & 70 & $0.410(0.307-0.458)$ & $0.607(0.458-0.669)$ & $0.302(0.185-0.362)$ \\
\hline Cebus capucinus & 106 & $0.387(0.274-0.419)$ & $0.596(0.477-0.668)$ & $0.298(0.178-0.329)$ \\
\hline Leptotila $\mathrm{sp}$. & 95 & $0.399(0.304-0.445)$ & $0.575(0.439-0.644)$ & $0.292(0.182-0.349)$ \\
\hline Crax rubra & 955 & $0.393(0.324-0.429)$ & $0.574(0.481-0.630)$ & $0.280(0.185-0.319)$ \\
\hline Ctenosaura similis & 175 & $0.194(0.134-0.230)$ & $0.385(0.291-0.469)$ & $0.156(0.951-0.221)$ \\
\hline
\end{tabular}

The underlying activity densities were calculated by kernel density estimation based on individual photograph times recorded between 2005 and 2015. The estimate of overlap for each pair of species is indicated with $95 \%$ bootstrap confidence interval in parenthesis.

$*_{\mathrm{n}}=$ sample size. 
at SRNP and 5075 at CNP (Digital Appendix 1 and Digital Appendix 2). Of these, 4009 and 2711 non-human, species-level records from SRNP and CNP, respectively, were used for statistical analysis (Table 1 and Table 2). Felid activity was slightly higher in the rainforests of CNP, where jaguars, pumas and ocelots were active $64 \%$ (CI: 0.36-0.69), $71 \%$ (CI: 0.51 0.82 ) and $52 \%$ (CI: $0.37-0.56)$ of the time, respectively; compared to $57 \%$ (CI: $0.47-0.65$ ), $58 \%$ (CI: 0.41-0.72) and $40 \%$ (CI: 0.32-0.50) of the time at SRNP. Activity schedules were predominantly nocturnal, with a probability of being active between 18:00-06:00 ranging from 0.66-0.71 for jaguars, $0.49-0.55$ for pumas and $0.79-0.81$ ocelots in the dry and rainforest, respectively. Activity peaks occurred near midnight for all cats except pumas in the dry forest, which increased their activity at dawn and at noon (Fig. 1).
Activity schedules of each felid species were very similar between the dry and rainforests with coefficients of overlap of 0.84 (CI: 0.83-0.99) for jaguars, 0.79 (CI: 0.69-0.89) for pumas and 0.83 (CI: 0.78-0.93) for ocelots. Interspecific temporal overlap was also high at each study site. Jaguar and puma were found to be active during the same hours $75 \%$ (CI $0.64-0.82)$ of the time in the dry forest and 80 $\%$ (CI 0.72-0.94) in the rainforest. Diel overlap between the puma and the ocelot ranged from 0.64 (CI 0.53-0.74) in the dry forest, to 0.73 (CI $0.65-0.83$ ) in the rainforests; while the coefficients of overlap for ocelots and jaguars were 0.82 (CI 0.0.76-0.90) in the dry forest and 0.81 (CI 0.74-0.95) in the rainforest (Fig. 2).

Temporal overlap with prey species varied with prey composition and abundance at each site (Digital Appendix 1 and Digital Appendix 2). In the dry forest, jaguars overlapped mainly

TABLE 2

Estimates of activity pattern overlap between the jaguar, puma and ocelot and their presumed prey species in the Corcovado National Park (CNP), Costa Rica

\begin{tabular}{lcccc}
\multicolumn{1}{c}{ Species } & $\mathrm{n} *$ & \multicolumn{2}{c}{ Coefficient of overlap $(95 \%$ Confidence interval) } \\
Tapirus bairdi & 112 & $0.782(0.700-0.915)$ & $0.729(0.636-0.830)$ & $0.842(0.776-0.920)$ \\
Procyon cancrivorus & 24 & $0.765(0.709-0.978)$ & $0.693(0.587-0.847)$ & $0.821(0.792-1.026)$ \\
Cuniculus paca & 112 & $0.66890 .543-0.791)$ & $0.599(0.490-0.681)$ & $0.779(0.679-0.849)$ \\
Didelphis marsupialis & 195 & $0.657(0.545-0.769)$ & $0.595(0.498-0.677)$ & $0.775(0.692-0.844)$ \\
Tamandua mexicana & 16 & $0.694(0.602-0.938)$ & $0.700(0.612-0.936)$ & $0.610(0.449-0.802)$ \\
Dasypus novemcinctus & 48 & $0.471(0.622-0.894)$ & $0.659(0.542-0.768)$ & $0.821(0.733-0.939)$ \\
Mazama americana & 28 & $0.589(0.418-0.716)$ & $0.637(0.514-0.781)$ & $0.475(0.301-0.576)$ \\
Conepatu semistriatus & 15 & $0.557(0.393-0.747)$ & $0.448(0.282-0.594)$ & $0.616(0.427-0.784)$ \\
Panthera onca & 49 & - & $0.797(0.722-0.942)$ & $0.803(0.747-0.955)$ \\
Tayuassu pecari & 149 & $0.543(0.376-0.630)$ & $0.616(0.510-0.700)$ & $0.397(0.279-0.446)$ \\
Leopardus pardalis & 133 & $0.806(0.746-0.955$ & $0.732(0.651-0.835)$ & - \\
Puma concolor & 111 & $0.797(0.722-0.942)$ & & - \\
Nasua narica & 56 & $0.520(0.341-0.619)$ & $0.606(0.474-0.696)$ & $0.391(0.243-0.443)$ \\
Pecari tajacu & 69 & $0.489(0.325-0.578)$ & $0.578(0.457-0.664)$ & $0.359(0.226-0.405)$ \\
Tinamus major & 163 & $0.494(0.341-0.567)$ & $0.512(0.407-0.567)$ & $0.381(0.248-0.398)$ \\
Eira barbara & 40 & $0.449(0.266-0.529)$ & $0.527(0.390-0.600)$ & $0.310(0.160-0.343)$ \\
Crax rubra & 278 & $0.438(0.280-0.510)$ & $0.513(0.419-0.576)$ & $0.288(0.185-0.320)$ \\
Dasyprocta punctata & 113 & $0.447(0.293-0.522)$ & $0.498(0.419-0.557)$ & $0.292(0.200-0.329)$ \\
\hline
\end{tabular}

The underlying activity densities were calculated by kernel density estimation based on individual photograph times recorded between 2003 and 2015. The estimate of overlap for each pair of species is indicated with $95 \%$ bootstrap confidence interval in parenthesis.

$*_{\mathrm{n}}=$ sample size. 

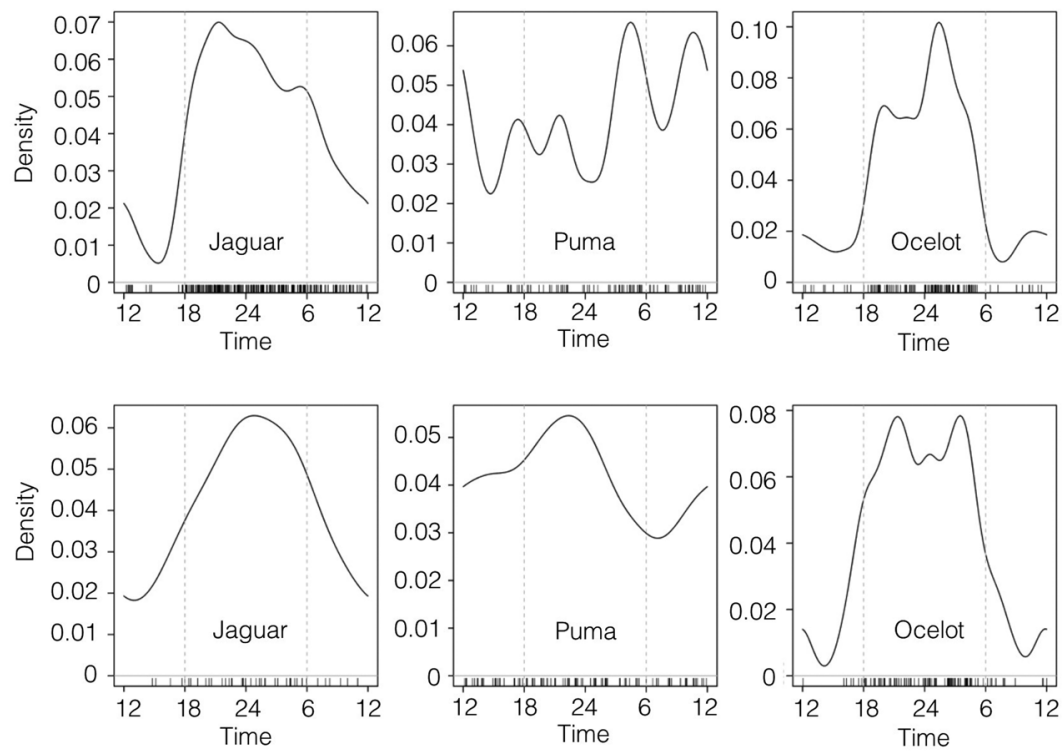

Fig. 1. Density estimates of the daily activity patterns of jaguar, puma and ocelot in the dry (SRNP; upper row) and rainforests (CNP; lower row) of Costa Rica. The short vertical lines above the $\mathrm{x}$-axis indicate the times of individual photographs recorded between 2003 and 2015, and the grey dashed vertical lines indicate the approximate time of sunrise and sunset.

with tapirs, armadillos and white-tailed deer; while in the rainforest, they matched the activity of pacas, ant eaters and brocket deer. Pumas, on the other hand, overlapped with a larger number of prey, including white-tailed deer, coatis, agoutis and crested guans in the dry forest, and with ant eaters, armadillos, brocket deer and peccaries in the rainforest. Ocelots overlapped mainly with opossums, armadillos and racoons at both sites (Table 1 and Table 2).

\section{DISCUSSION}

Activity of jaguars, pumas, and ocelots may vary significantly from place to place as a result of changes in environmental conditions such as prey availability (Rabinowitz \& Nottingham, 1986; Quigley \& Schaller, 1988; Sunquist \& Sunquist, 2002; Harmsen, Foster, Silver, Ostro, \& Doncaster, 2011), competition (Taber et al., 1997; Romero-Muñoz et al., 2010), seasonality (Emmons, 1987; Carrillo, Fuller, \& Sáenz, 2009), and human disturbances (Paviolo, Di Blanco, De Angelo, \& Di Bitetti,
2009). In this study, the activity schedules of each cat did not vary significantly between sites; however, the three felids displayed higher activity levels in the rainforest than in the dry forest. The latter could derive from differences in prey composition and availability between sites, which could cause predators to spend more or less time securing their prey (Sunquist \& Sunquist, 1989; Cruz-Díaz, 2012; Montalvo, 2012). Alternatively, the higher temperatures observed in the SRNP could exert an influence on the activity of felids. Previous research has shown that increases in temperature have a negative effect on the activity of felids and other mammals (Crawshaw \& Quigley, 1991; Mills \& Biggs, 1993; Sunquist, 1981). Podolski, Belotti, Bufka, Reulen, \& Heurich (2013), for instance, determined that Eurasian Lynx (Lynx lynx) decreased their activity by $30 \mathrm{~min}$ for every $10{ }^{\circ} \mathrm{C}$ increase in temperature. In the SRNP temperature can reach $46{ }^{\circ} \mathrm{C}$ (unpublished data) while surface water virtually disappears from some areas of the park during the driest months. Such conditions could force 

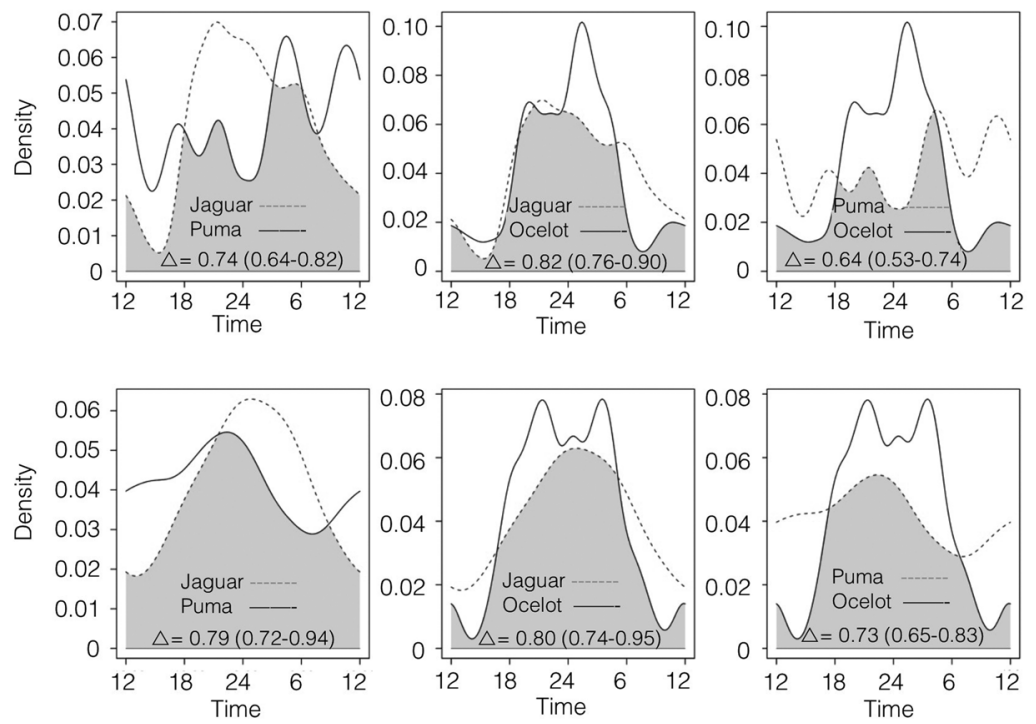

Fig. 2. Estimates of the daily activity patterns of jaguars, pumas and ocelots in the dry (SRNP; upper row) and rainforests (CNP; lower row) of Costa Rica. The dash and solid lines are kernel density estimates for the indicated species based on individual photograph times recorded between 2003 and 2015. The overlap coefficient is the area under the minimum of the two density estimates, as indicated by the shaded area in each plot. The estimate of overlap is indicated in each plot with $95 \%$ bootstrap confidence interval in parenthesis.

animals to decrease their activity in order to conserve energy and avoid dehydration (Scognamillo et al., 2003).

Despite the strong temporal overlap observed between the felids, fine-scale differences in their activity schedules are likely to contribute to their local coexistence. Not only did the cats differ in their activity peaks but they also showed different degrees of nocturnality. The ocelot, for example, was strongly nocturnal, while the jaguar displayed certain level of diurnal activity but was mostly recorded at night. Pumas, on the other hand, were similarly active by day and night. Partitioning of time has been observed in other carnivore assemblages (Arjo \& Pletscher; 1999; Azlan \& Sharma, 2006; Di Bitetti et al., 2009). Di Bitetti et al. (2010), observed different levels of temporal segregation, with some species displaying apposite schedules (jaguarundi and margay) while others differed in their activity peaks or were active at any time of the day (puma and oncilla). Although in our case, time might not be the primary segregation mechanism, it probably plays a role in the local coexistence of these felid communities.

As we predicted, the pairs of cats with the highest morphological similarity (puma-jaguar and puma-ocelot) had a smaller temporal overlap (and therefore, a strongest separation) than the more morphologically-distinct jaguar and ocelot. It is likely that the ecological niches of the jaguar and the ocelot are too different for competition to take place (Davies et al., 2010). It has been determined that jaguars and ocelots have very little diet overlap, with $92 \%$ of the ocelots' prey weighing less than one $\mathrm{kg}$, while $85 \%$ of jaguar's prey weighed more than one $\mathrm{kg}$ (Emmons, 1987). Pumas, on the other hand, may consume a high proportion ( $100 \%$ in some cases) of the prey species taken by jaguars and ocelots (Crawshaw, 1995). Similar investigations (Polis, Myers, \& Holt, 1989; Palomares \& Caro, 1999) suggested that competition for food is a key factor precipitating intraguild killing (the most extreme form of interference competition). For instance, extensive dietary overlap among large African 
carnivores was correlated with high levels of interspecific aggression (Schaller, 1972; Mills \& Biggs, 1993). If spatial and trophic overlap are common in our felid assemblage, the temporal segregation of the daily activity patterns could be an effective mechanism to reduce competition (Carothers \& Jaksic, 1984). Furthermore, a stronger partitioning of time should be expected between the species with the highest diet similarity (puma-ocelot and puma-jaguar), as was observed in this and other studies (DiBitetti et al., 2010).

Jaguars, pumas and ocelots have been described as opportunistic predators whose movements and activity schedules largely depend on those of their major prey (Rabinowitz \& Nottingham, 1986; Quigley \& Schaller, 1988). Due to the weak temporal segregation observed between our felids, it is likely that their activity schedules resulted largely from the activity patterns of their prey. Jaguars, for example, showed a significant $(>50 \%)$ time overlap with tapirs, deer and white-lipped peccaries, three of the most frequently detected species in this study (Digital Appendix 1 and Digital Appendix 2). Ocelots, on the other hand, were highly nocturnal, matching the activity of opossums, armadillos and raccoons (Digital Appendix 3 and Digital Appendix 4). Previous investigations determined that jaguars in the CNP changed their activity and movement patterns every two weeks, depending on the availability of marine turtles, a large, predictable and easily-hunted prey (Carrillo et al,. 2009; Herrera, 2016).

In conclusion, segregation of activity patterns does not appear to be the principal mechanism facilitating the coexistence of jaguars, pumas and ocelots in our study areas. Other factors, such as space use or prey availability, may play a fundamental role in determining felids' behavior and community structure. However, fine-scale (e.g. activity peaks) or spatiotemporal differences in the activity schedules of predators might contribute to their coexistence in these environments. Activity of prey seems to be a stronger predictor of the felids' activity. High overlapping coefficients between the jaguar, puma and ocelot and their potential prey species suggest that these cats synchronize their activity with that of their prey. Predators that hunt when the probability of prey capture is greatest should have greater prey capture success, and at lower cost, than individuals that forage at random (Gantchoff \& Belant, 2016). Moreover, if predators exist at low densities and direct confrontations are uncommon, the benefits of foraging at times when prey activity is high may outweigh the costs of proximity to dominant competitors (Davies et al., 2010). Research at the interface between habitat use, resource utilization and temporal distribution of prey and potential competitors may provide valuable insight into the mechanisms underlying species coexistence in neotropical felid communities (Chesson, 2000).

\section{ACKNOWLEDGMENTS}

This study received financial support from the U.S. Fish and Wildlife Service, the Wild Felid Research and Management Association, The Rufford Foundation, Idea Wild, the Jaguar Program and the National University of Costa Rica.

\section{RESUMEN}

Separación temporal del jaguar Panthera onca, puma Puma concolor y ocelote Leopardus pardalis (Carnivora: Felidae) en los bosques tropicales húmedos y secos de Costa Rica. La segregación de los patrones de actividad diaria es considerado un importante mecanismo para la coexistencia de especies competidoras. En este estudio, evaluamos si existía separación temporal entre el jaguar (Panthera onca), puma (Puma concolor) y ocelote (Leopardus pardalis), y si sus patrones de actividad se relacionaban con los de sus presas potenciales. Utilizamos registros de cámaras trampa para estimar los patrones de actividad de los felinos y sus presas. Usamos el coeficiente de traslape $(\Delta ;$ de 0 a 1$)$ para cuantificar las interacciones temporales entre depredadores y presas y calculamos los intervalos de confianza mediante bootstrapping. Observamos un fuerte traslape temporal $(\Delta=0.63-0.82)$ entre los felinos tanto en el bosque seco como en el lluvioso. La mayor segregación temporal ocurrió entre los competidores más cercanos (jaguar y puma, puma y ocelote). El jaguar y el puma tuvieron un fuerte traslape con las presas medianas y grandes, mientras que el ocelote se traslapó con presas 
más pequeñas. Los altos coeficientes de traslape entre los felinos sugieren que la segregación temporal no es el mecanismo principal de coexistencia en estos sitios. Sin embargo, pequeñas diferencias en los patrones de actividad (e.g. picos de actividad desfasados) podrían contribuir a su coexistencia en ambientes tropicales.

Palabras clave: Área de Conservación Guanacaste; coexistencia; competencia por interferencia; felinos silvestres; Parque Nacional Corcovado; patrones de actividad; segregación temporal.

\section{REFERENCES}

Arjo, W. M., \& Pletscher, D. H. (1999). Behavioral responses of coyotes to wolf recolonization in northwestern Montana. Canadian Journal of Zoology, 77, 1919-1927.

Azlan, J. M., \& Sharma, D. S. K. (2006). The diversity and activity patterns of wild felids in a secondary forest in Peninsular Malaysia. Oryx, 40, 36-41.

Barrull, J., Mate, I., Ruiz-Olmo, J., Casanovas, J. G., Gosalbez, J., \& Salicru, M. (2014). Factors and mechanisms that explain coexistence in a Mediterranean carnivore assemblage: an integrated study based on camera trapping and diet. Mammalian Biology, 79, 123-31.

Carothers, J. H., \& Jaksic, F. M. (1984). Time as a niche difference: the role of interference competition. Oikos, 42, 403-406.

Carrillo, E. (2000). Ecology and conservation of whitelipped peccaries and jaguars in Corcovado National Park (Unpublished doctoral thesis). University of Massachusetts, USA.

Carrillo, E., Fuller, T. K., \& Sáenz, J. (2009). Jaguar (Panthera onca) hunting activity: effects of prey distribution and availability. Journal of Tropical Ecology, 25, 563-567.

Chesson, P. (2000). General theory of competitive coexistence in spatially-varying environments. Theoretical Population Biology, 58, 11-237.

Crawshaw, P. G. Jr. (1995). Comparative ecology of ocelot (Felis pardalis) and jaguar (Panthera onca) in a protected subtropical forest in Brazil and Argentina (Unpublished doctoral thesis). University of Florida, USA.

Crawshaw, P. G., \& Quigley, H. B. (1991). Jaguar spacing, activity and habitat use in a seasonally flooded environment in Brazil. Journal of Zoology, 22, 357-370.

Crawshaw, P. G., \& Quigley, H. B. (2002). Hábitos alimentarios del jaguar y el puma en el pantanal, Brasil, con implicaciones para su manejo y conservación.
En R. A. Medellin et al. (Ed.), El Jaguar en el Nuevo Mileno (pp. 223-235). Ciudad de Mexico: Fondo de Cultura Económica-UNAM-Wildlife Conservation Society.

Cruz-Díaz, J. C. (2012). Ecología y cambios en la abundancia de jaguar (Panthera onca), puma (Puma concolor), ocelote (Leopardus pardalis) y sus presas potenciales en el Parque Nacional Corcovado, Costa Rica (Unpublished master's thesis). Universidad Nacional, Costa Rica.

Davies, T. J., Meiri, S., Barraclough, T. G., \& Gittleman, J. L. (2007). Species co-existence and character divergence across carnivores. Ecology Letters, 10, 146-152.

Davies, M. L., Kelly, M. J., \& Stauffer, D. F. (2010). Carnivore co-existence and habitat use in the Mountain Pine Ridge Forest Reserve, Belize. Animal Conservation, 14, 56-65.

Dayan, T., \& Simberloff, D. (2005). Ecological and community-wide character displacement: the next generation. Ecology Letters, 8, 875-894.

Di Bitetti, M. S., Di Blanco, Y. E., Pereira, J. A., Paviolo, A., \& Pérez, I. J. (2009). Time partitioning favors the coexistence of sympatric crab-eating foxes (Cerdocyon thous) and pampas foxes (Lycalopex gymnocercus). Journal of Mammalogy, 90, 479-490.

Di Bitetti, M. S., Angelo, C. D., Di Blanco, Y. E., \& Paviolo, A. (2010). Niche partitioning and species coexistence in a Neotropical felid assemblage. Acta Oecologica, 36, 403-412.

Donadio, E., \& Buskirk, S. W. (2006). Diet, morphology, and interspecific killing in Carnivora. The American Naturalist, 167, 524-536.

Emmons, L. H. (1987). Comparative feeding ecology in a neotropical rainforest. Behavioral Ecology \& Sociobiology, 20, 271-283.

Foster, V., Sarmento, P., Sollmann, R., Torres, N., Jacomo, A., Negroes, N., ... Silveira, L. (2013). Jaguar and puma activity patterns and predator-prey interactions in four Brazilian biomes. Biotropica, 45, 373-379.

Gantchoff, M. G., \& Belant, J. L. (2016). Patterns of coexistence between two mesocarnivores in northern Patagonia in the presence of invasive hares and anthropogenic disturbance. Austral Ecology, 41, 97-105.

Gonzalez-Borrajo, N., Lopez-Bao, J. V., \& Palomares, F. (2016). Spatial ecology of jaguars, pumas, and ocelots: a review of the state of knowledge. Mammal Review, 47, 62-75.

Harmsen, B. J., Foster, R. J., Silver, S, C., Ostro, L. E. T., \& Doncaster, C. P. (2009). Spatial and temporal interactions of sympatric jaguars (Panthera onca) 
and Pumas (Puma concolor) in a neotropical forest. Journal of Mammology, 90, 612-620.

Harmsen, B. J., Foster, R. J., Silver, S. C., Ostro, L. E. T., \& Doncaster, C. P. (2011). Jaguar and puma activity patterns in relation to their main prey. Mammalian Biology, 76, 320-324.

Herrera, H. (2016). Actividad diaria y depredación de tortugas marinas por el jaguar (Panthera onca) en el Parque Nacional Santa Rosa, Costa Rica (Unpublished master's thesis). Universidad Nacional, Costa Rica.

Janzen, D. H. (1988). Guanacaste National Park: tropical, ecological and biocultural restoration. In J. Jr. Cairns (Ed.), Rehabilitating damaged ecosystems (pp. 143192). Florida, USA: CRC Press.

Karanth, K. U., \& Sunquist, M. E. (2000). Behavioural correlates of predation by tiger (Panthera tigris), leopard (Panthera pardus) and dhole (Cuon alpinus) in Nagarahole, India. Journal of Zoology, 250, 255-265.

Kenagy, G. J. (1973). Daily and seasonal patterns of activity and energetics in a heteromyid rodent community. Ecology, 54, 1201-1219.

Kronfeld-Schor, N., \& Dayan, T. (2003). Partitioning of time as an ecological resource. Annual Review of Ecology, Evolution \& Systematics, 34, 153-181.

Leite, M. R. P., \& Galvaõ, F. (2002). El jaguar, el puma y el hombre en tres áreas protegidas del bosque atlántico costero de paraná, Brasil. En R. A. Medellin et al. (Ed.), El Jaguar en el Nuevo Mileno (pp. 237-250). Ciudad de México: Fondo de Cultura EconómicaUNAM-Wildlife Conservation Society.

Linkie, M., \& Ridout, M. S. (2011). Assessing tiger-prey interactions in Sumatran rainforests. Journal of Zoology, 284, 224-229.

MacArthur, R. H., \& Levins, R. (1967). The limiting similarity, convergence and divergence of coexisting species. American Naturalist, 101, 377-385.

Mills, M. G. L. \& Biggs, H. C. (1993). Prey apportionment and related ecological relationships between large carnivores in Kruger National Park. In N. Dunstone \& M. L. Gorman (Eds.), Mammals as predators (pp. 253-268). London, England: Symposia Zoological Society of London.

Mondolfi, E., \& Hoogesteijn, R. (1986). Notes on the biology and status of the jaguar (Panthera onca) in Venezuela. In S. D. Miller, \& D. D. Everett (Eds.), Cats of the world: biology, conservation and management (pp. 85-123). Washington, USA: National Wildlife Federation.

Montalvo, G. V. H. (2012). Cambios en la abundancia, actividad temporal y dieta del jaguar (Panthera onca), otros felinos $y$ sus presas en el Parque
Nacional Santa Rosa, Costa Rica (Unpublished master's thesis). Universidad Nacional, Costa Rica.

Novack, A. J., Main, M. B., Sunquist, M. E., \& Labisky, R. F. (2005). Foraging ecology of jaguar (Panthera onca) and puma (Puma concolor) in hunted and non-hunted sites within the Maya Biosphere Reserve, Guatemala. Journal of Zoology, 267, 167-178.

Nuñez, R., Miller, B., \& Lindzey, F. (2000). Food habits of jaguars and pumas in Jalisco, Mexico. Journal of Zoology, 252, 373-379.

O'Farrell, M. J. (1974). Seasonal activity patterns of rodents in a sagebrush community. Journal of Mammalogy, 55, 809-823.

Pacheco, C. (1994). Hábitos alimentarios y uso estacional de hábitat de la pava crestada (Penelope purpurascens) en el bosque tropical seco, Parque Nacional Santa Rosa, Costa Rica (Unpublished master's thesis). Universidad Nacional, Costa Rica.

Palomares, F., \& Caro, T. M. (1999). Interspecific killing among mammalian carnivores. American Naturalist, 153, 492-508.

Paviolo, A. N., Di Blanco, Y. E., De Angelo, C. D., \& Di Bitetti, M. S. (2009). Protection affects the abundance and activity patterns of pumas in the Atlantic forest. Journal of Mammalogy, 90, 926-934.

Podolski, I., Belotti, E., Bufka, L., Reulen, H., \& Heurich, M. (2013). Seasonal and daily activity patterns of free-living Eurasian lynx Lynx lynx in relation to availability of kills. Wildlife Biology, 19(1), 69-77.

Polis, G. A., Myers, C. A., \& Holt, R. D. (1989). The ecology and evolution of intraguild predation: potential competitors that eat each other. Annual Review of Ecology and Systematics, 20, 297-330.

Quigley, H. B., \& Schaller, G. B. (1988). Ecology and conservation of the jaguar in the Pantanal region of Brazil. Washington, USA: National Geographic Society.

R Development Core Team. (2017). R: A language and environment for statistical computing. R Foundation for Statistical Computing. Vienna, Austria. Retrieved from https://www.R-project.org

Rabinowitz, A. R., \& Nottingham, B. G. (1986). Ecology and behavior of the jaguar (Panthera onca) in Belize, Central America. Journal of Zoology, 210, 149-159.

Ridout, M. S., \& Linkie, M. (2009). Estimating overlap of daily activity patterns from camera trap data. Journal of Agricultural, Biological and Environmental Statistics, 14, 32-337.

Romero-Muñoz, A., Maffei, L., Cuéllar, E., \& Noss, A. J. (2010). Temporal separation between jaguar and puma in the dry forests of southern Bolivia. Journal of Tropical Ecology, 26, 303-311. 
Rosenzweig, M. L. (1966). Community structure in sympatric Carnivora. Journal of Mammalogy, 47, 602-612.

Schaller, G. B. (1972). The Serengeti lion. Chicago, USA: University of Chicago Press.

Schaller, G. B., \& Crawshaw, P. G. Jr. (1980). Movement patterns of jaguar. Biotropica, 12, 161-168.

Schoener, T. W. (1974). Resource partitioning in ecological communities. Science, 185, 27-38.

Scognamillo, D. G., Maxit, I., Sunquist, M., \& Polisar, J. (2003). Coexistence of jaguar (Panthera onca) and puma (Puma concolor) in a mosaic landscape in the Venezuela llanos. Journal of the Zoological Society of London, 259, 269-279.

Silver, S., Ostro, L., Marsh, L., Maffei, L., Noss, A., Kelly, M., ... Ayala, G. (2004). The use of camera traps for estimating jaguar (Panthera onca) abundance and density using capture/recapture analysis. Oryx, 38(2), 148-154.

Sunquist, M. E. (1981). The social organization of tigers (Panthera tigris) in Royal Chitawan National Park, Nepal. Smithsonian Contributions to Zoology, 339, $1-98$.

Sunquist, M. E., \& Sunquist, F. C. (1989). Ecological constraints on predation by large felids. In J. Gittleman (Ed.), Carnivore behavior, ecology, and evolution (pp. 283-301). New York, USA: Cornell University Press.

Sunquist, M., \& Sunquist, F. (2002). Wild cats of the world. Chicago: University of Chicago Press.

Taber, A. B., Novaro, A. J., Neris, N., \& Colman, F. H. (1997). The food habits of sympatric jaguar and puma in the Paraguayan Chaco. Biotropica, 29, 204-213.

See Digital Appendix at: / Ver Apéndice digital en:

revistas.ucr.ac.cr 